\title{
Chromosomal DNA Probes for the Identification of Bacteroides Species
}

\author{
By MARILYN C. ROBERTS, ${ }^{1 *}$ BERNARD MONCLA ${ }^{2}$ AND \\ GEORGE E. KENNY ${ }^{1}$ \\ ${ }^{1}$ Departments of Pathobiology ${ }^{1}$ and Periodontics and Oral Biology ${ }^{2}$, University of Washington, \\ Seattle, WA 98195, USA
}

(Received 11 November 1986; revised 27 January 1987)

We compared 22 Bacteroides species by DNA-DNA homology studies using the S1 endonuclease method. None of the currently defined species shared more than $30 \%$ DNA homology with any other species examined with the exception of B. buccae and B. capillus (which along with $B$. pentosaceus are now considered a single species), which shared $86 \%$ of their DNA sequences. Two clusters showed weak genetic relationships, with DNA homology $>10 \%$. The first cluster included $B$. corporis, $B$. disiens, $B$. bivius, $B$. intermedius and $B$. melaninogenicus. The second cluster included $B$. fragilis, B. eggerthii, $B$. ovatus, $B$. thetaiotaomicron and $B$. uniformis. Five of the oral species, $B$. asaccharolyticus, $B$. gingivalis, $B$. loescheii, $B$. intermedius and $B$. melanogenicus, were chosen for study as whole chromosomal probes in dot blot assays. These were tested against 243 clinical strains biochemically identified as Bacteroides species. The DNA probes correctly identified $94 \%$ of the clinical strains. DNA probe and biochemical identification was $100 \%$ for two of the five species. In contrast, only $86 \%$ of the strains biochemically identified as $B$. intermedius were identified by the DNA probe. The DNA probes gave a species identification to seven strains which could not be biochemically identified.

\section{INTRODUCTION}

The genus Bacteroides consists of a diverse group of Gram-negative, obligately anaerobic, non-spore-forming rods (Johnson, 1973; Holdeman et al., 1982). Some species are pathogenic for humans and animals and many are found as normal flora in a variety of anatomical sites (Williams \& Holt, 1985). Separation of Bacteroides species by biochemical tests has been difficult (Johnson \& Ault, 1978). Many of the recently described new species represent elevations of previous subspecies ranks to the species level based on nucleic acid studies (Cato \& Johnson, 1976; Holdeman et al., 1984). In other cases, new species represent the identification of new distinct taxa (Coykendall et al., 1980; Holdeman \& Johnson, 1977, 1982; Holdeman et al., 1982; Jackson \& Goodman, 1978; Johnson \& Holdeman, 1983; Mitsuoka et al., 1974; van Steenbergen et al., 1981, 1984; Watabe et al., 1983; Werner et al., 1983). No comprehensive study of the DNA homology between the various species has been published. The limited data available are fragmented, having been obtained in different laboratories using different techniques. As a result the DNA-DNA homology between the various species within the genus is not clear. Recently a comprehensive study of rRNA homology values among Bacteroides strains was published (Johnson \& Harich, 1986). The majority of the Bacteroides strains tested fell into one of three clusters. The intracluster rRNA homology values ranged from 35 to $100 \%$, and intercluster homology values were about $25 \%$. However, homology between Escherichia coli and the Bacteroides rRNA ranged from 4 to $29 \%$, suggesting the conservation of rRNA sequences between genetically (at the DNA level) dissimilar genera.

Recently we found that DNA dot blots could be used to identify clinical strains of the new anaerobic genus Mobiluncus (Roberts et al., 1984, 1985). The two species of Mobiluncus share 9$25 \%$ of their DNA sequences and show no DNA homology with other established genera 
(Spiegel \& Roberts, 1984). The DNA dot blot provided a simple method of identifying and confirming the identity of the strains as Mobiluncus, and was more reproducible than any of the currently available biochemical tests. We were interested in determining whether a similar type of assay could be developed for identifying oral Bacteroides species, some of which are thought to play a role in periodontal disease (Holdeman et al., 1982; Loesche et al., 1982; Tanner et al., 1979; White \& Mayrand, 1981).

\section{METHODS}

Strains. The 23 Bacteroides species in the study included the 21 listed by Holdeman et al. (1984) for the proposed type strain for each species. Each strain was obtained from the American Type Culture Collection (ATCC) and verified biochemically: B. asaccharolyticus ATCC 25260, B. bivius ATCC 29303, B. buccae ATCC 33574, B. capillus ATCC 33690, B. corporis ATCC 33547, B. denticola ATCC 33185, B. disiens ATCC 29426, B. distasonis ATCC $8503, B$. eggerthii ATCC 27754, B. fragilis ATCC 25285, B. gracilis ATCC 33236, B. gingivalis ATCC $33277, B$. intermedius ATCC 25611, B. loescheii ATCC 15930, B. melaninogenicus ATCC 25845, $B$. multiacidus ATCC 27723, B. oris ATCC $33573, B$. ovatus ATCC 8483, B. splanchnicus ATCC 29572, B. thetaiotaomicron ATCC 29148, B. uniformis ATCC 8492, B. ureolyticus ATCC 33387, B. vulgatus ATCC 8482. Two hundred and forty-two clinical strains isolated from the oral cavity and one genital isolate which had been biochemically identified using the API AnIdent system and VPI system (Holdeman et al., 1977) were tested in the dot blot assay. These included $2 \mathrm{~B}$. asaccharolyticus, $70 \mathrm{~B}$. gingivalis, $23 \mathrm{~B}$. loescheii, $106 \mathrm{~B}$. intermedius, $35 \mathrm{~B}$, melaninogenicus and 7 Bacteroides species. Other strains used included: Eubacterium lentum ATCC 2559, E. saburreum ATCC 33271, E. timidum ATCC 33092, E. plautii ATCC 29863, E. nodatum ATCC 33099, Eikenella corrodens ATCC 23834, Selenomonas sputigena ATCC 33150, Fusobacterium nucleatum ATCC 23726, $F$. gonidiaformans ATCC 25563, Haemophilus aphrophilus ATCC 19415, Actinomyces naeslundii ATCC 12104, A. viscosus ATCC 15987, A. odontolyticus ATCC 17929, A. israeli ATCC 12102, Rothia dentocariosa ATCC 17931, Capnocytophaga gingivalis ATCC 33624, C. ochracea ATCC 33596, Arachnia propionica ATCC 14157, Peptostreptococcus micros ATCC 33270, Wolinella recta ATCC 33238, Veillonella parvula ATCC 10790, and Actinobacillus actinomycetemcomitans ATCC 29522. Field strains of many of these species were also tested. Field strains of Staphylococcus aureus and Bacteroides forsythus were also used.

Patient selection and sampling. Patients with various forms of periodontal disease were obtained from the periodontal clinic at the University of Washington. Subgingival samples were taken from 5-10 mm periodontal pockets using a Morse scaler. The samples were placed in $2 \mathrm{ml}$ prereduced Hanks' balanced salts solution containing $10 \%(\mathrm{v} / \mathrm{v})$ heat-inactivated horse serum and transported to an anaerobic glove box within $10 \mathrm{~min}$. The plaque was dispersed by a $5 \mathrm{~s}$ pulse on low power from a micro-ultrasonic cell disrupter (Kontes). Samples were spotted onto nitrocellulose and serial dilutions were prepared in the same medium and plated on prereduced blood agar plates for bacterial identification. Plates were incubated for $7-10 \mathrm{~d}$ in an anaerobic environment at $35^{\circ} \mathrm{C}$.

Media. Blood agar plates were prepared using Columbia blood agar base (Difco) as described by the manufacturer. Each lot of plates was quality controlled. Other media were prepared as described in the VPI Manual (Holdeman et al., 1977). The liquid medium used to grow large quantities of bacteria for preparation of DNA was a soy-peptone fresh yeast extract dialysate broth (Kenny, 1967), or enriched trypticase soy broth (Syed, 1980).

DNA extraction and purification. Each strain was grown in $700-1000 \mathrm{ml}$ liquid medium for $5-7 \mathrm{~d}$ at $37{ }^{\circ} \mathrm{C}$ in an anaerobic environment. The DNA extraction method was as previously described for use with Mobiluncus spp. (Spiegel \& Roberts, 1984).

$D N A-D N A$ hybridization. DNA was isolated from each of the strains. The DNA from 23 strains representing 22 species of Bacteroides (two strains, B. capillus and $B$. buccae, are now placed in a single species) was labelled by nick translation, using $0.5 \mu \mathrm{g}$ DNA, $\left[{ }^{3} \mathrm{H}\right]$ thymine $5^{\prime}$-triphosphate and three unlabelled nucleotide triphosphates (Roberts et al., 1984; Spiegel \& Roberts, 1984). The unincorporated radiolabel was separated from the labelled double-stranded DNA by passage through a $15 \mathrm{~cm}$ Sephadex G-75 column. The probes were stored at $-10^{\circ} \mathrm{C}$ and used within 3 weeks. The radiolabelled probes were diluted and concentrations of 5000 total c.p.m. were used as probes. Test DNA $(15 \mu \mathrm{g})$ and $5000 \mathrm{c} . \mathrm{p} . \mathrm{m}$. of radioactive probe DNA were mixed, denatured, hybridized overnight at $65^{\circ} \mathrm{C}$, and the amount of reassociation was assayed with Sl endonuclease (Spiegel \& Roberts, 1984). The levels of reassociation of unlabelled homologous DNA and unlabelled heterologous DNA (calf thymus DNA) with each labelled probe DNA served as controls in each experiment. The heterologous control measured the amount of self-annealing of the probe $(\leq 10 \%)$ and this value was subtracted from all other values. The homologous control always had $\geq 75 \%$ of the total probe activity. Test results were normalized to $100 \%$ for the homologous DNAs and all other values normalized. Duplicate tests were run for each assay on two to four separate occasions. The results in Table $\mathrm{I}$ are the means of these separate runs. Individual assays varied from each other by $\pm 2 \%$. 
Dot blots. DNA $(0 \cdot 1 \mu \mathrm{g})$ was nick translated as previously described (Roberts et al., 1984) using two ${ }^{32}$ P-labelled nucleotide triphosphates and two unlabelled nucleotide triphosphates. The unincorporated radiolabel was separated from the labelled double-stranded DNA by passage through a $15 \mathrm{~cm}$ Sephadex G-75 column. The probes were stored at $-10{ }^{\circ} \mathrm{C}$ and used within a week. Organisms were grown on blood agar plates at $35^{\circ} \mathrm{C}$ for $2 \mathrm{~d}$, then growth was removed with a sterile cotton applicator and transferred to sterile saline. The density of the suspensions were adjusted to $0.5 \mathrm{MacFarland}$ units and $5 \mu \mathrm{l}$ of organisms was then spotted onto nitrocellulose paper. Filters were treated to release and fix the DNA to the nitrocellulose paper and stored until needed at room temperature (Roberts et al., 1984). Routinely, 20-30 clinical strains plus controls were spotted on one piece of nitrocellulose and five replicates were prepared of each filter so that one could be tested with each probe. The filters were pretreated at $42{ }^{\circ} \mathrm{C}$ for $\geqslant 1 \mathrm{~h}$ with a solution containing $50 \%(\mathrm{w} / \mathrm{v})$ formamide, $1 \%(\mathrm{w} / \mathrm{v}) \mathrm{glycine}$, $50 \mathrm{~mm}$-sodium phosphate, $0.02 \%(\mathrm{w} / \mathrm{v})$ polyvinylpyrollidone, $0.1 \%(\mathrm{w} / \mathrm{v})$ albumin, $0.1 \%(\mathrm{w} / \mathrm{v}) \mathrm{Ficoll}, 0.9 \mathrm{M}-\mathrm{NaCl}$, $0.05 \mathrm{M}$-monobasic sodium phosphate, $0.005 \mathrm{M}$-EDTA, $0.055 \mathrm{M}-\mathrm{NaOH}$ and $100 \mu \mathrm{g}$ boiled calf thymus DNA ml $\mathrm{m}^{-1}$. They were then drained and incubated overnight at $42{ }^{\circ} \mathrm{C}$ in a solution containing $50 \%(\mathrm{v} / \mathrm{v})$ formamide, $1 \%(\mathrm{w} / \mathrm{v})$

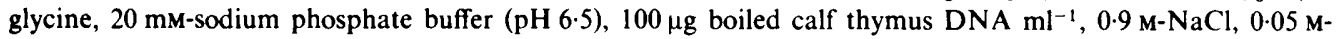
monobasic sodium phosphate, $0.005 \mathrm{M}$-EDTA, $0.02 \%(\mathrm{w} / \mathrm{v})$ polyvinylpyrollidone, $0.02 \%(\mathrm{w} / \mathrm{v})$ albumin, $0.02 \%$ $(\mathrm{w} / \mathrm{v})$ Ficoll, $0.055 \mathrm{~m}-\mathrm{NaOH}, 10 \%$ (w/v) sodium dextran sulphate $\left(M_{\mathrm{r}} 500000\right), 100 \mu \mathrm{g}$ boiled calf thymus DNA $\mathrm{ml}^{-1}$, and boiled ${ }^{32} \mathrm{P}$-labelled probe $\left(10^{8}\right.$ c.p.m. per $\mu \mathrm{g}$ DNA). The filters were then removed and washed three times at room temperature with $250 \mathrm{ml}$ of a solution containing $0.002 \mathrm{M}$-EDTA, $0.02 \mathrm{M}$-monobasic sodium phosphate, $0.36 \mathrm{M}-\mathrm{NaCl}$ and $0.1 \%(\mathrm{w} / \mathrm{v}) \mathrm{SDS}$, followed by two washes at $50{ }^{\circ} \mathrm{C}$ in $500 \mathrm{ml}$ of a solution containing $0.001 \mathrm{M}$-EDTA, $0.001 \mathrm{M}$-monobasic sodium phosphate, $0.18 \mathrm{M}-\mathrm{NaCl}$ and $0.1 \%(\mathrm{w} / \mathrm{v}) \mathrm{SDS}$. The filters were dried and exposed overnight to Kodak X-omat AR film at $-70^{\circ} \mathrm{C}$ and then developed (Roberts et al., 1984).

\section{RESULTS AND DISCUSSION}

In order to determine the genetic relationships between the organisms classified in the genus Bacteroides, we carried out a reciprocal cross-comparison using 20 probes representing 20 species, by the $\mathrm{S} 1$ endonuclease method (Table 1 ). We also included $B$. capillus to test its relatedness to $B$. buccae. These two strains have recently been placed into a single species along with the strain originally named $B$. pentosaceus (Johnson \& Holdeman, 1985). Two additional probes, $B$. gracilis and $B$. denticola, were tested against the panel of 20 species, $B$. capillus and themselves in a one-way cross. This is the first time that a single laboratory has examined this number of strains using a single method and at a single time. Overall, the Bacteroides species were remarkably distinct. Only 50 of the 180 cross-hybridizations (excluding the 20 homologous reactions) in the reciprocal cross-comparisons showed homology of $10 \%$ or greater (Table 1 ). $B$. gracilis, $B$. denticola and $B$. capillus were tested in one-way cross-comparisons and only 6 of the 43 hybridizations (excluding the 3 homologous reactions) showed homology of $10 \%$ or greater. The $B$. capillus vs $B$. buccae reaction was considered a homologous one, since they are now considered a single species. Two clusters of species showed weak reciprocal homology and were determined by the reciprocal cross-hybridizations having a value greater than $10 \%$. The first cluster included $B$. corporis, $B$. disiens, $B$. bivius, $B$. intermedius and $B$. melaninogenicus. $B$. denticola may also be linked to this cluster but since only one-way crosses were examined this is not clear. The second cluster comprised B. fragilis, B. eggerthii, B. ovatus, B. thetaiotaomicron and B. uniformis. These two groups are very similar to the clusters reported using rRNA probes (Johnson \& Harich, 1986) but the homology using rRNA probes was significantly higher than what we found using chromosomal DNA as the probe. The largest homology observed was with the two strains labelled B. buccae and B. capillus $(86 \%)$. Similar values $(82-87 \%)$ have been reported in other studies (Johnson \& Holdeman, 1985). In our study the DNA homologies between B. buccae and the other species was very similar to the results obtained between $B$. capillus and the other species. This would be predicted and provides further evidence of their genetic similarity.

For seven of the species, we compared our data with those from several other DNA-DNA homology studies in which a variety of methods and strains were used (Bradbury et al., 1985; Cato et al., 1976; Cooper et al., 1984; Johnson, 1978; Johnson \& Ault, 1978) (Table 2). In many cases, the values obtained in other laboratories are compatible and within $\pm 3 \%$ of the data presented in this paper. One pair which is significantly different is $B$. ovatus vs $B$. thetaiotaomicron which, in our study, had $18-20 \%$ homology while other laboratories report 22 
omuap $g$ or

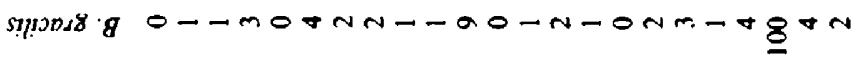
spsing g bmart-nonnanmo=ー-ナ+g \&

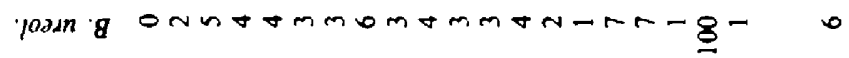

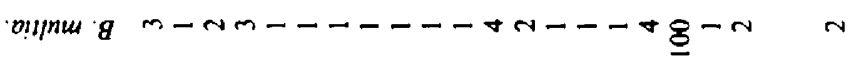

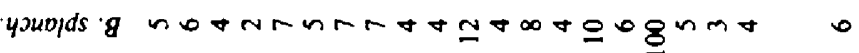

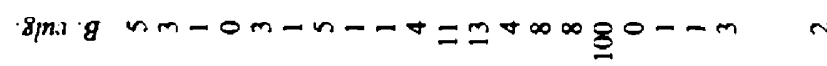

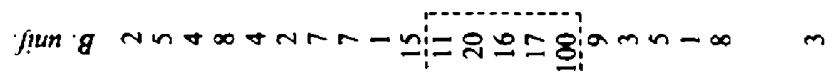

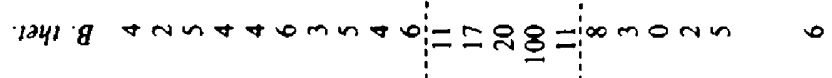

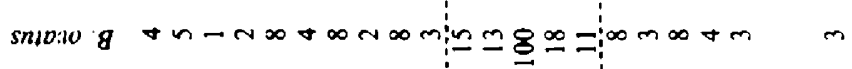

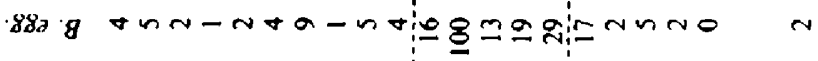
youfg

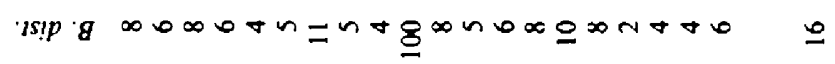

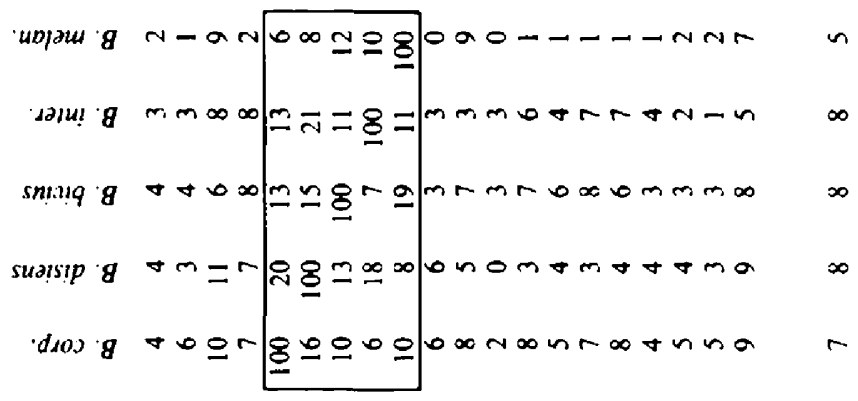

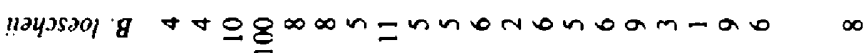

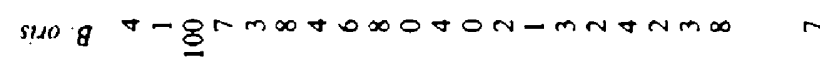

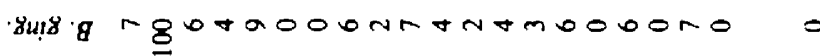

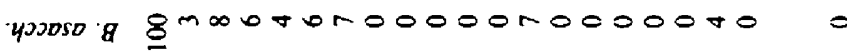

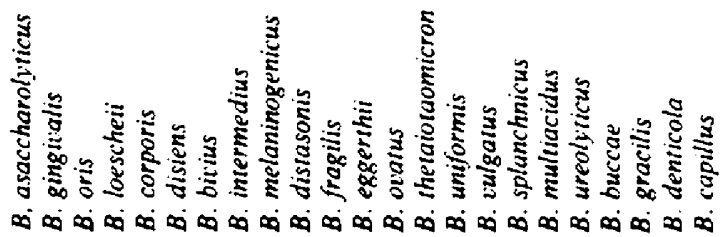


Table 2. Comparison of DNA-DNA homologies obtained in this study with those of the literature

The actual extent of binding of ${ }^{3} \mathrm{H}$-labelled DNA with the unlabelled chromosomal DNA of the parent strain was $75-85 \%$; however, all were set at $100 \%$ and all other values were normalized to give relative homology. Values in parenthesis were taken from the literature (Cato \& Johnson, 1976; Johnson, 1973, 1978; Johnson \& Ault, 1978).

Labelled probe:

\begin{tabular}{|c|c|c|c|c|c|c|c|}
\hline $\begin{array}{l}\text { Unlabelled DNA } \\
\text { B. distasonis }\end{array}$ & B. dist. & $\begin{array}{l}\text { B. frag. } \\
(8-21)\end{array}$ & $\begin{array}{l}\text { B. egg. } \\
\text { (3) }\end{array}$ & $\begin{array}{c}\text { B. ovatus } \\
(0-3)\end{array}$ & $\begin{array}{c}\text { B. thet. } \\
(4-7)\end{array}$ & $\begin{array}{r}\text { B. unif. } \\
(5-10)\end{array}$ & $\begin{array}{c}\text { B. vulg. } \\
(0-7)\end{array}$ \\
\hline B. fragilis & $\begin{array}{l}100 \\
(5)\end{array}$ & 7 & 4 & $\begin{array}{c}3 \\
(9-24)\end{array}$ & $\begin{array}{c}6 \\
(21-28)\end{array}$ & $\begin{array}{c}15 \\
(17-21)\end{array}$ & $\begin{array}{c}4 \\
(10-20)\end{array}$ \\
\hline B. eggerthii & $\begin{array}{l}8 \\
8 \\
(8)\end{array}$ & $\begin{array}{c}100 \\
(25-28)\end{array}$ & 16 & $\begin{array}{c}15 \\
(12-18)\end{array}$ & $\begin{array}{c}11 \\
(17-23)\end{array}$ & $\begin{array}{c}11 \\
(25-58)\end{array}$ & $\begin{array}{c}11 \\
(20-26)\end{array}$ \\
\hline B. otatus & $\begin{array}{c}5 \\
(0-4)\end{array}$ & $\begin{array}{c}10 \\
(9-24)\end{array}$ & 100 & 13 & $\begin{array}{c}17 \\
(39-40)\end{array}$ & $\begin{array}{c}20 \\
(9-21)\end{array}$ & $\begin{array}{c}13 \\
(0-8)\end{array}$ \\
\hline B. thetaiotaomicron & $\begin{array}{c}6 \\
(5-7)\end{array}$ & $\begin{array}{c}19 \\
(21-30)\end{array}$ & $\begin{array}{c}13 \\
(21-23)\end{array}$ & $\begin{array}{c}100 \\
(22-49)\end{array}$ & 20 & $\begin{array}{c}16 \\
(3-28)\end{array}$ & $\begin{array}{c}4 \\
(4-28)\end{array}$ \\
\hline B. uniformis & $\begin{array}{c}8 \\
(6-14)\end{array}$ & $\begin{array}{c}25 \\
(9-28)\end{array}$ & $\begin{array}{c}19 \\
(29-62)\end{array}$ & $\begin{array}{c}18 \\
(9-100)\end{array}$ & $\begin{array}{c}100 \\
(14-40)\end{array}$ & 17 & $\begin{array}{c}8 \\
(9-29)\end{array}$ \\
\hline B. vulgatus & $\begin{array}{c}10 \\
(6-24) \\
12\end{array}$ & $\begin{array}{c}9 \\
(0-9) \\
8\end{array}$ & $\begin{array}{c}29 \\
(6-14) \\
17\end{array}$ & $\begin{array}{c}11 \\
(0-16) \\
8\end{array}$ & $\begin{array}{c}11 \\
(9-17) \\
8\end{array}$ & $\begin{array}{c}100 \\
(0-20) \\
9\end{array}$ & 100 \\
\hline
\end{tabular}

$49 \%$ and $39-40 \%$ depending on which strain was used as the probe and which as the test. The reciprocal values within our testing conditions are identical, suggesting that the difference seen when $B$. thetaiotaomicron (39-40\%) was used as a probe may be due to differences in the strains tested or in the method for assaying homology. Other differences between our data and previous work were seen between $B$. uniformis vs $B$. ovatus, for which homology ranged from $9-100 \%$ in other studies while it was $11 \%$ in this study. Similarly, homology between $B$. uniformis vs $B$. thetaiotaomicron ranged from 14 to $40 \%$ and between $B$. uniformis vs $B$. eggerthii from 25 to $58 \%$ in other studies, whereas values of $11 \%$ and $20 \%$ respectively were obtained in this study.

Many of the Bacteroides spp. are difficult to differentiate from each other by classical phenotypic and biochemical tests, yet appear to share very litle genetic homology. This is similar to the problem described for the new anaerobic genus Mobiluncus (Roberts et al., 1984, 1985). Mobiluncus strains are difficult to isolate, maintain and identify to species level; however, we have found identification by chromosomal DNA dot blot to be a convenient and reliable way of confirming an identification of species within the genus even though two species share $9-25 \%$ homology (Spiegel \& Roberts, 1984). Most of the Bacteroides species share $<30 \%$ DNA homology with other species in the genus. This suggests that the dot blot assay could be used to speciate strains of Bacteroides.

We prepared whole-cell DNA probes from five oral Bacteroides species: $B$. asaccharolyticus, $B$. gingivalis, B. loescheii, B. intermedius and B. melaninogenicus. Some of these bacteria are thought to play a role in periodontal disease. When each probe was tested against the other species in dot blot assays, using purified DNA, no hybridization was seen between each of the probes and any of the other species. In contrast, a good reaction occurred with the homologous probe and homologous test DNA. Similar results were seen when whole bacteria were spotted instead of pure DNA. The bacterial cell density of whole organisms was not critical as long as a minimum of $10^{4}$ bacteria were spotted. Other bacteria often found in the oral cavity were also tested and included: Eubacterium lentum, E. saburreum, E. timidum, E. plautii, E. nodatum, Capnocytophaga gingicalis, C. ochracea, Eikenella corrodens, Selenomonas sputigena, Fusobacterium nucleatum, F. gonidiaformans, Haemophilus aphrophilus, Actinomyces naeslundii, A viscosus, A. odontolyticus, A. israelii, Rothia dentocariosa, Arachnia propionica, Peptostreptococcus micros, Staphylococcus aureus, Wolinella recta, Veillonella parvula, Bacteroides forsythus and Actinobaccilius actinomycetemcomitans. These included biochemically identified field and reference strains. None of these species cross-reacted with the five Bacteroides probes. 
Table 3. Identification of clinical strains by DNA probes

\author{
Clinical strains \\ identified biochemically \\ B. asaccharolyticus $(n=2)$ \\ $B$. intermedius $(n=106)$ \\ B. gingitalis $(n=70)$ \\ B. loescheii $(n=23)$ \\ B. melaninogenicus $(n=35)$ \\ B. melaninogenicus \\ or $B$. denticola $(n=3)$ \\ Bacteroides sp. $(n=4)$
}

\begin{tabular}{|c|c|c|c|c|}
\hline \multicolumn{5}{|c|}{ Positive by DNA probe } \\
\hline B. asacch. & B. inter. & B. ging. & B. loescheii & B. melan. \\
\hline 2 & 0 & 0 & 0 & 0 \\
\hline 0 & 93 & 0 & 0 & 0 \\
\hline 0 & 0 & 70 & 0 & 0 \\
\hline 0 & 0 & 0 & 22 & 0 \\
\hline 0 & 0 & 0 & 0 & 33 \\
\hline 0 & 1 & 0 & 1 & 1 \\
\hline 0 & 1 & 0 & 2 & 1 \\
\hline
\end{tabular}

We tested 236 clinical isolates biochemically identified as: $B$. asaccharolyticus (1 genital and 1 oral), 70 oral $B$. gingivalis, 23 oral $B$. loescheii, 106 oral $B$. intermedius and 35 oral $B$. melaninogenicus (Table 3). Two of the five DNA probes ( $B$. asaccharolyticus and $B$. gingivalis) identified all of the strains identified by biochemical tests as the same species. The $B$. intermedius probe missed $12 \%$ of the biochemically identified strains. These missed strains may represent the $B$. intermedius type II strains which share only $40 \%$ homology with the $B$. intermedius type I strains (Johnson \& Harich, 1986). Our probe strain was a type I strain. A type II strain is being prepared and will be used to examine these non-reactive strains. It is also possible that these strains biochemically type as $B$. intermedius but genetically resemble one or more other Bacteroides species. We are at present determining whether these strains react with other members of the 22 species examined in this study. However, it is possible that these bacteria represent one or more new species. Twenty-two out of $23(96 \%)$ B. loescheii strains, and 33 out of $35(94 \%)$ B. melaninogenicus strains, were confirmed by DNA dot blot as the species identified by biochemical tests.

Seven strains could not be biochemically assigned to species (Table 3), but all were identified when tested against the five probes. The three strains identified as either $B$. melaninogenicus or $B$. denticola were identified by DNA probes as one strain each of $B$. intermedius, $B$. loescheii and $B$. melaninogenicus, while the four strains identified as Bacteroides $\mathrm{sp}$. were identified as one each of $B$. intermedius and $B$. melaninogenicus and two of $B$. loescheii. Successful identification of this small group of strains suggests that the dot blot assay could help identify strains which are ambiguous by biochemical identification schemes.

The dot blot assay required on the average $36 \mathrm{~h}$ to complete, while the biochemical testing required 7-21 d. The DNA probes will provide for more definitive identification of the species because small genetic changes leading to phenotypic variation will not be detected by the whole genomic probe assay.

Our results indicate that the nitrocellulose blot is a quick method of identifying Bacteroides isolates to species, and from our DNA-DNA homology data it is apparent that whole chromosomal probes prepared from any of the species examined should provide a specific probe for identifying the majority of the strains isolated in the laboratory. The advantage of this system is that cloning is not required, the genetic organization of the species need not be known and the probability of the probe recognizing all members of the species is very high. In contrast, with cloned probes a number of different fragments need to be tested for specificity. In the study reported by Salyers et al. (1983), only two of the five cloned fragments which were screened hybridized specifically with $B$. thetaiotaomicron and no other Bacteroides species. The other problem with cloned fragments is that they may not react with all members of the species, as was reported by Kuritza et al. (1986). In that report, some of the isolated fragments were specific for the type I or type II subgroup of $B$. fragilis and reacted only with strains from the same subgroup. Finally, if single-copy genes are used as the probe fragment, the sensitivity can be as much as 100 -fold less as compared to multicopy genes or whole chromosomal DNA probes (McLafferty et al., 1986). 
This study was funded by a Public Service Grant DE02600 and the Hack Memorial Fund. We thank D. J. Bridenbaugh, L. Daughtry, J. Kirihara, C. Tompkins and K. Trautman for technical support.

\section{REFERENCES}

Bradbury, W. C., Murray, R. G. E., Mancini, C. \& MORRIS, V. L. (1985). Bacterial chromosomal restriction endonuclease analysis of the homology of Bacteroides species. Journal of Clinical Microbiology 21, 24-28.

Cato, E. P. \& Johnson, J. L. (1976). Reinstatement of species rank for Bacteroides fragilis, $B$. ovatus, $B$. distasonis, $B$. thetaiotaomicron, and $B$. vulgatus: designation of neotype strains for Bacteroides fragilis (Veillon and Zuber) Castellani and Chalmers and Bacteroides thetaiotaomicron (Distaso) Castellani and Chalmers. International Journal of Systematic Bacteriology 26, 230-237.

COOPER, S. W., SZYMCZAK, E. G., JaCOBS, N. V. \& TALLY, F. P. (1984). Differentiation of Bacteroides ovatus and Bacteroides thetaiotaomicron by means of bacteriophage. Journal of Clinical Microbiology 20, $395 \cdots 403$.

Coykendall, A. L., Kaczmarek, F. S. \& Slots, J. (1980). Genetic heterogeneity in Bacteroides asaccharolyticus (Holdeman and Moore 1970) Finegold and Barnes 1977 (Approved Lists, 1980) and proposal of Bacteroides gingiralis sp. nov. and Bacteroides macacae (Slots and Genco) comb. nov. International Journal of Systematic Bacteriology 30 , 559-564.

Holdeman, L. V. \& Johnson, J. L. (1977). Bacteroides disiens sp. nov. and Bacteroides bitius sp. nov. from human clinical infections. International Journal of Systematic Bacteriology 27, 337-345.

Holdeman, L. V. \& Johnson, J. L. (1982). Description of Bacteroides loescheii sp. nov. and recommendation of the descriptions of Bacteroides melaninogenicus (Oliver and Wherry) Roy and Kelly 1939 and Bacteroides denticola Shah and Collins 1981. International Journal of Sy'stematic Bacteriology 32, 399-409.

Holdeman, L. V., Cato, E. P. \& Moore, W. E. C. (editors) (1977). Anaerobe Laboratory Manual, 4th edn. Blacksburg, Virginia: Virginia Polytechnic Institute and State University.

Holdeman, L. V., Moore, W. E. C., Churn, P. J. \& JoHNSON, J. L. (1982). Bacteroides oris and Bacteroides buccae, news species from human periodontitis and other human infections. International Journal of Systematic Bacteriology 32, 125-131.

Holdeman, L. V., Cato, E. P. \& Moore, W. E. C. (1984). Taxonomy of anaerobes: present state of the art. Reviews of Infectious Diseast' 6, S3-S10.

JACKSON, F. L. \& GoOdman, Y. E. (1978). Bacteroides ureolyticus, a new species to accommodate strains previously identified as 'Bacteroides corrodens, anaerobic'. International Journal of Systematic Bacteriology 28, $197-200$

Johnson, J. L. (1973). Use of nucleic-acid homologies in the taxonomy of anaerobic bacteria. International Journal of Systematic Bacteriology 23, 308315.

JoHnson, J. L. (1978). Taxonomy of the Bacteroides. I. Deoxyribonucleic acid homologies among Bacteroides fragilis and other saccharolytic Bacteroides species. International Journal of Systematic Bacteriology 28, 245-256
Johnson, J. L. \& Ault, D. A. (1978). Taxonomy of the Bacteroides. II. Correlation of phenotypic characteristics with deoxyribonucleic acid homology groupings for Bacteroides fragilis and other saccharolytic Bacteroides species. International Journal of Systematic Bacteriology 28, 257-268.

JOHNSON, J. L. \& HARICH, B. (1986). Ribosomal ribonucleic acid homology among species of the genus Bacteroides. International Journal of Systematic Bacteriology 36, 71-79.

Johnson, J. L. \& Holdeman, L. V. (1983). Bacteroides intermedius comb. nov. and descriptions of Bacteroides corporis sp. nov. and Bacteroides levii sp. nov. International Journal of Systematic Bacteriology 33, $15-25$.

Johnson, J. L. \& Holdeman, L. V. (1985). Bacteroides capillus Kornman and Holt and Bacteroides pentosaceous Shah and Collins, later synonyms of Bacteroides buccae Holdeman et al. International Journal of Systematic Bacteriology 35, 114.

KenNY, G. E. (1967). Heat stability and organic solvent solubility of Mycoplasma antigens. Annals of the New York Academy of Sciences 143, 676-681.

Kuritza, A. P., Getty, C. E., Shaughnessy, P., Hesse, R. \& Salyers, A. A. (1986). DNA probes for identification of clinically important Bacteroides species. Journal of Clinical Microbiology 23, 343-349.

Loesche, W. J., Syed, S. A., Stoll, J.\& Loughan, B. E. (1982). The bacteriology of acute necrotizing ulcerative gingivitis. Journal of Periodontology 53, 223-230.

Mclafferty, M. A., Harcus, D. R., Weiss, A. A., Sapian, L. A. \& HewletT, E. L. (1986). Development of a DNA probe for identification of Bordetella pertussis. Abstracts of the Annual Meeting of the American Society for Microbiology, p. 356.

Mitsuoka, T., Terada, A., Watanabe, K. \& Uchida, K. (1974). Bacteroides multiacidus, a new species from the feces of humans and pigs. International Journal of Systematic Bacteriology 24, 35-41.

Roberts, M. C., Hillier, S. L., SChoenkneCht, F. D. \& Holmes, K. K. (1984). Nitrocellulose filter blots for species identification of Mobiluncus curtisii and Mobiluncus mulieris. Journal of Clinical Microbiology 20, 826-827.

Roberts, M. C., Hillier, S. L., SChoenkneCht, F. D. \& Holmes, K. K. (1985). Comparison of gram stain, DNA probe, and culture for the identification of Mobiluncus spp. Journal of Infectious Diseases 152, 74-77.

Salyers, A. A., LynN, S. P. \& Gardner, J. F. (1983). Use of randomly cloned DNA fragments for identification of Bacteroides thetaiotaomicron. Journal of Bacteriolog. 154, 287-293.

SPIEgel, C. A. \& Roberts, M. (1984). Mobiluncus gen. nov., Mobiluncus curtisii subspecies curtisii sp. nov., Mobiluncus curtisii subspecies holmesii subsp. nov., and Mobiluncus mulieris sp. nov., curved rods from the human vagina. International Journal of Systematic Bacteriology 34, 177-184. 
van Steenbergen, T. J. M., VilaAnderen, C. A. \& DE GRAAFF, J. (1981). Confirmation of Bacteroides gingivalis as a species distinct from Bacteroides asaccharolyticus. International Journal of Systematic Bacteriology 31, 236-241

VAN Steenbergen, T. J. M., VAN Winkelhoff, A. F. MAYRAND, D., Grenier, D. \& DE GraAF, J. (1984). Bacteroides endodontalis sp. nov., an asaccharolytic black-pigmented Bacteroides species from infected dental root canals. International Journal of Systematic Bacteriology 34, 118-120.

SYED, S. A. (1980). Characteristics of Bacteroides asaccharolyticus from dental plaques of beagle dogs. Journal of Clinical Microbiology 11, 522-526.

Tanner, A. C. R., Hoffer, C., Brathall, G. T., Visconti, R. A. \& Socransky, S. S. (1979). A study of the bacteria associated with advancing periodontitis in man. Journal of Clinical Periodontology 6, 278307.
Watabe, J., Benno, Y. \& Mitsuoka, T. (1983). Taxonomic study of Bacteroides oralis and related organisms and proposal of Bacteroides veroralis $\mathrm{sp}$. nov. International Journal of Systematic Bacteriology 33, 57-64.

Werner, H., Rintelen, G. \& Kunstek-Santos, H. (1975). A new butyric acid-producing Bacteroides species: $B$. splanchnicus $\mathrm{n}$. $\mathrm{sp}$. Zentralblatt für Bakteriologie, Mikrobologie und Hygiene A231, 133144.

White, D. \& Mayrand, D. (1981). Association of oral Bacteroides with gingivitis and adult periodontitis. Journal of Periodontal Research 16, 259-265.

Williams, G. D. \& Holt, S. C. (1985). Characteristics of the outer membrane of selected oral Bacteroides species. Canadian Journal of Microbiology 31, 238250 . 